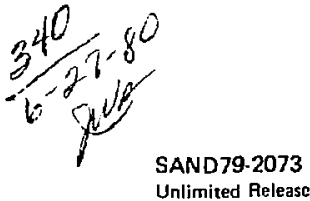

\title{
Biological Studies of the United States Subseabed Disposal Program
}

ep

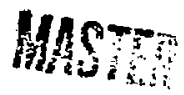

L. S. Gomez, R. R. Hessler, D. W. Jackson, M. G. Marietta,

K. L. Smith, Jr., D. M. Taibert, A. A. Yayanos

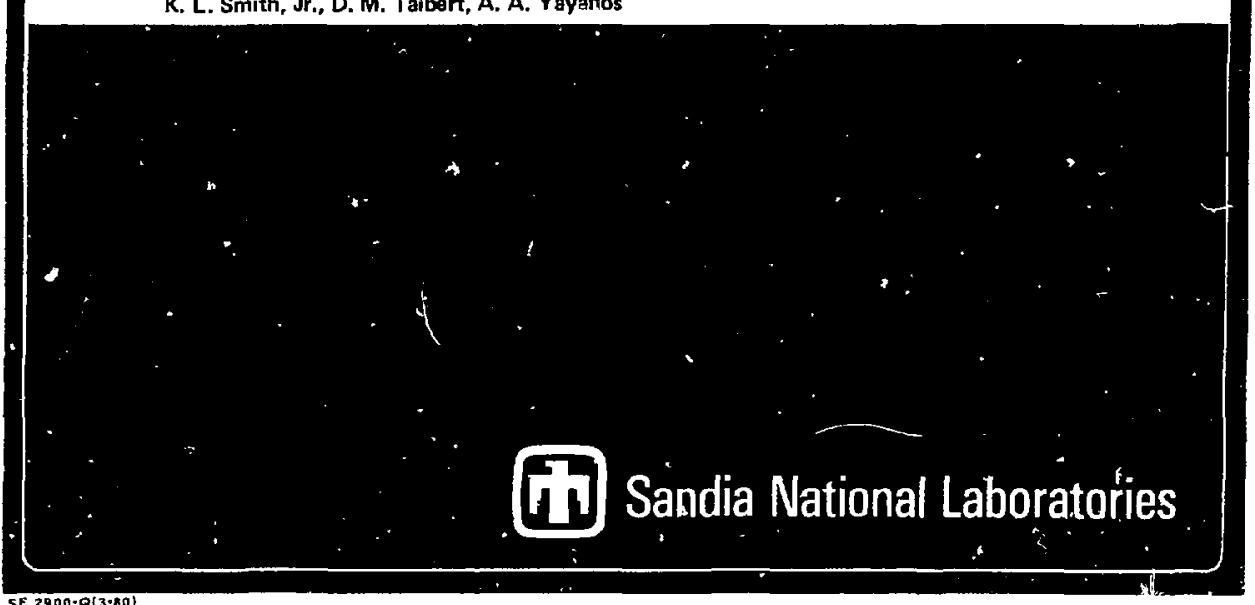


SAND79-2073

Un?imited Release
Distirbution

category UC-70

BIOLOGICAL STUDIES OF THE U.S. SLBSEABED DISPOSAL PROGRAM

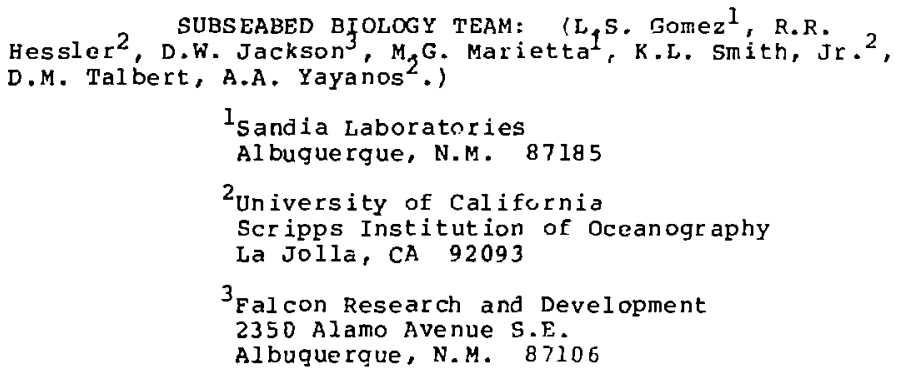

ABSTRACT

The Subseabed Disposal Program (SDP) of the U.S. is assessing the feasibility of emplacing high level zadioactive wastes (HLW) within deep-sea sediments and is developing the means for assessing the feasibility of the disposal practices of other nations. This paper discusses the role and status of bioiogical research in the SDP. Studies of the disposal methods and of the conceived barriers (canister, waste form and sediment) suggest that biological knowledge will be principally needed to address the impact of accidental releases of radionuclides. Current experimental work is focusing on the deep-sea ecosystem to determine: (1) the structure of benthic communities, including their microbial component; (2) the faunal composition of deep midwater nekton; (3) the biology of deep-sea amphipods; (4) benthic community metabolism; (5) the rates of bacterial processes; (6) the metabolism of deep-sea aninals, and 17) the radiation sensitivity of deep-sea organisms. A multicompartment model is being developed to assess guantitatively, the impact (on the environment and on man) of releases of radionuclides in to the sea.

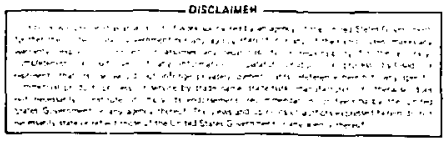




\section{BIOLOGICAL STUDIES OF THE U. S. SUBSEABED PROGRAM}

INTRODUCT ION

on a world-wide scale the nuclear fuel cycle is producing an ever increasing amount of waste. A recent review (McElroy and Burns, 1979) describes concisely the several options being investigated in the U.S. for the disposal of high level $r$ adioactive wastes (HLW). The deep sea is among the loci being considered as potentially suitable. Anderson (1979) has written a current report on the U.S. Subseabed Disposal Program (SDP), which has two overall objectives: (1) to determine the feasibility of emplacing HLW within selected deep-sea sediments; and (2) to develop a capability for assessing the Eeasibility of the practices of other nations disposing radioactive wastes into the marine environment. The research and development goals at the operational level of the SDP are to achieve or analyze site selection, multibartier description, emplacement procosses, tranaportation considerations, societalpolitical aspects, risk, economics, and environmental impact. The biological aspects of the research, the subject of this paper, are relevant to most of these goals.

The disposal of appropriately packaged and solidified HLW in the seabed differs from many of the other geological options being evaluated in that the marine environment could be affected. In addition, other geologic disposal methods might also require transportation by ship if one nation were to use the land disposal site or reprocessing facility of another nation. A ship carrying HLíi destined for cisposal on land or into the seabed could accidently be lost at sea. Another kind of aucident could occur if there were a failure to emplace fackaged HLW into the sediments. Once the waste is successfully buried, the canister and waste form should contain the radionuciides for hundreds of years. During this period the ecosystem should be minimally affected. After the canister and waste form corrode ano disintegrate, however, then $r$ adionuclides will interact with sediments. These interactions should result in virtually all of the $r$ adionuclides being sorbed onto the sediments (Duursma and Gross, 1971; Heath, et al., 1979). But we do not yet know if all radionuclides and their chemical forms will be sorbed, and processes yet to be fully evaluated may result in some release to the benthic boundary layer where interaction with deep-sea life would occur. Clearly, the evaluation of accidental releases makes biological research necessary. Finally, biological research may al low for the design of sensitive monitoring programs (Schaefer, $(1960)$. 
Radioactivity of man-made origin has been entering the marine environment by several mechanisms for decades. The continuing study of the pathways of these radionuclides provides much of the necessary information needed for assessing the impact of a deep-sea disposal plan. Low level wastes have been disposed by the U.S. (Ccean Dumping, 1970) and are being disposed by a consortium of nations (European Nuclear Energy Agency, 1969) onto the sea floor. Some of the low level disposal sites in the deep sea have been studied (e.g., Noshkin, et a.l., (1978). Nevertheless, the bulk of our knowledge of the pathways to mis and of the impact of radioactivity in the marine environment is derived mainly from shallow water situations such as the Bikini tests affecting the Pacific Ocean (e.g., Japan Society for the Promotion of Science, 1956), the Windscale effluents into the Irish Sea (e.g.. Preston, 1975), and the Hanford discharges into the Pacific Ocean via the Columbia River (e.g. Pearcy, et al.. 1977). The point is that the radioecological data base is most deficient in the deep sea. Indeed, biological knowledge in general about the deep sea is lagging behind that of shallow waters. In part this situation is due to the virtually virgin nature of many deep-sea resources. Research to achieve management of these resources has thus been unnecessary. The burgeoning world population will result in closer scrutiny of the food resources of the deep sea; the need for minerals is already causing examination of the deep-sea floor; waste disposal (some radioactive) into the marine environment is already a reality-even if not yet for $\mathrm{HLW}$. There is a desire to use a given resource of the deep sea without affecting others, and consequently research in deep-sea biology is beginning to be stimulated world wide.

On account of this dearth of basic biological knowledge of the deep sea, much of the research in the SDP to date has had mainly to do with deep-sea ecology. The radioecology of the deep sea will be more directly addressed this coming year because of the successes in basic deep-sea ecology over the past few years. What follows is a description of the highlights of the biological aspects of the ongoing U.S. SDP program and an indication of the directions it will be taking over the next year.

Workshops internal to the Subseabeo Disposal Program, as well as international workshops help to identify the important problems of $H L W$ in the deep sea. A Biology Task Group is one of seven Task Groups of the Seabed Working Group of the NEARadioactive piaste Management Committee. The Seabed Working Group meetings provide an international forum on all aspects of $\mathrm{ALW}$ in the deep sea by identifying cooperative research efforts, providing information exchange and evaluating progress. 
Finally, it should be noted that the SDP has a scheduie a iming to provide a demonstration of the capability to emplace canisters by approximately 1990-95. A more immediate milestone is to show the technical and environmental feasibility of the SDP concept by the end of 1983 .

\section{Development of an Ecosystem Model}

There are a large number of biological and physical events whose interactions may transport radionuclides released inadvertently into the environment. Food for marine organisms is synthesized by phytoplankton in surface waters. This is the beginning of the nourishment of marine organisms ranging in size from bacteria to the largest of animals, blue whales. Feeding and excretion transfer material through the $E$ abr ic of the seas. Migrations of the animals themselves are also important. Certain marine mammals and birds exhibit annual horizontal migrations of thousands of miles. Salmon, shad and other $F$ ishes have dramat ic anadromous migrations. Many commercial fishes reproduce with pelagic egge transported horizontally for tens of miles (Pussell, 1976). Vertical migrations in the water column are no less profound, ranging from a diel pattern (Longhurst, 1976) over hundreds of meters to the ontogenetic migration of rattails (Merrett, 1973) that can extend over a few thousarid meters. Some benthic invertebrates have pelagic eggs or larvae that may disperse horizontally. These and other biological interactions are influenced by an assortment of physical processes such as currents, eddies, upwellings, and thermal structure.

A mathematical model which describes the migration of radionuclides by the various transport mechanisms (physical as well as biological) of the sea is being developed in order to guantify the impact due to any accidental release of waste materiol. This model is directed towards answering two guestions: what is the effect upon the marine environment, and what is the effect upon man? The goal is to estimate the levels of $r$ adioactivity in marine organisms and the dose to man.

The model is made up of the following modules: near-field transport in sediments with heat effects; far-field isothermal transport in the sediments; physical and biological transport; human dosimetry; affected human populations; and finally, human health effects. The resultant human health effects studies will answer the guestion concerning the ef fect on man. The concentrations of radioactivity predicted in the physical and biological transport module will provide part of the answer for the guestion concerning ecosystem effects. rnowledge of how a given concertration of radiaactivity will affect particular organisms will 
be gained through an investigation of the radiosensitivity of deep-sea organisms. Predictions of effects on the ecosystem inferred from the studies on inalviduals shodla be confirmed experimentally.

The oceanic ecosystem has been compartmental ized in a manner begun by wishner (1977) by grouping organisms according to the ir function. The species within a compartment are assumed to benave similarly both in their relationships with the environment and in the way that they pass along radionuclides. Group bounds on the standing crop and metabolic rates may then be assigned to each compartment by observing the constituents of the group. Further, the module for the water column and biological transport has been separated into sub-models, reflecting the different mixing layers of the water column. The benthic boundary layer part of the model extends from the lower limit of biological activity in the sediments and extends $i_{:}:=0$ the bottom. 20-50 meters of the water column. Above the boundary layer is a multi-layered moủei.

The mass transports between biological compartments and physical compartments are most complex. Besides predator-prey relationships, the radionuclioes may be transported by excretion, mortality, adsorftion, migration (feeding, breeding, and ontogenetic), and molting. In addition, both organic and inorganic sediments and/or particulate materials may be consumed. Radionuclides may also be taken up directly froin the water column or from the interstitial water of the sediments. There are various physical transports to be considered, such as association-disassociation in the sediments and water column for both organic and inorganic matter, erosionsedimentation, vertical and horizontal water dispersion, bioturbation, horizontal migration of benthic megafauna, vertical migration of midwater animals, and dispersion of host particulate matter. Each of these radionurlide transports between compartments is be ing examined.

Modelers and experimenters of the SDP meet bimonthly to develop the proper mathematical expressions for the biological transports in the model. While a deep-sea data base is being obtained, it is being supplemented with shallow water data in order to exercise the model. In addition, some algorithms for computing the transfer rates have been adopted.

Biology of Near-Eield and Far-Field Regions

In the SDP concept, HLW would be buried in sediments 30 to 100 meters beneath the sediment water interface. The near-field region is that immediately surrounding the canister; the far-field region 
extends to a spherical surface whose $r$ adius comes up to the zone of active animals in the sediments. The biological questions in these regions are mainly microbiological. These, along $w i t h$ chemical and physical processes (see Krumbein, 1978; Gieskes, 1975), are involved in the diagenetic events in sediments. The need for a greater understanding of the microbiological processes is widely recognized. Are there metabolically active or potentially metabolically active microbes at these sediment depths? Can microbiological activities affect (adversely or favorably) the canister, the waste form, or the sediment-radionuclide interactions at 30 to 100 meter sediment depths? We would not expect organisms to survive in the near-field region or in the adjoining parts of the far-rield regions because of thermal and radiation effects.

About three years ago a core about $24.5 \mathrm{n}$ long was taken (Hollister, 1977) with a giant piston corer and was sampled for microbes (Yayanos and van Boxtel, 1977). The samples were preserved by several methods (Ereezing, freeze drying, and chemical fixation). Organic carbon content ranged from 0.068 to 0.158 $(w / w)$. ATP (adenos ine triphosphate--a component of living but not of dead cells) was present at depths shallower than ten meters and in a single sample at about a $24 \mathrm{~m}$ depth. This coula have been due to a contaminant. The use of ATP is a tenuous method For determining the presence of cells. In using it to detect low cellular concentrations, for example, contaminat ion from gear and the experimenter can be a difficulty. These froblems could be minimized. Yet the chief source of uncertainty would remain, due to the length of time it takes to retrieve and dismantle a large corer to allow sampling. ITP content of cells would most likely change during such delays. We plan to analyze some of the other samples (frozen and freeze dried) using microscopy this coming year. In order to achieve an analysis of many microscopic fields of view we will use computer-assisted image analysis. The variety of methods of sample preparation to be investigated includes fluorescent labelling for microbes.

Cultivation of microbes is one of the most sensitive ways to detect their presence. Eecause of the well-known uncertainty involved the above indirect methods of microbial detection are also being explored. We have endeavored, however, to find cultivation conditions for deep-sea microbes. Rather than tackle the cultivation problem for the microbes of deep sediments first --even though these $m i g h i$ be of most interest during the first few hundred years of emplacement--we have chosen to solve cultivation difficulties using microbes whose existence is guite apparent--those that participate in putrefaction. our success has been encouraging (Dietz and rayanos, 1978; Yayanos, Lietz and Van Boxtel, 1979) with the isolation of genuine deep-sea microorganisms. We have many isolates but have only studied 
one in detail. This isolate (designated CNET-3, and originating in the central North Pacific Ocean) grows rapidly (a generation time of about 9 hours at deep-sea pressures and temperatures). We are studying its growth reguirements to find out which of the many cultivation variables are significant. CNPT-3 dies when decompressed at increased temperatures (above $15^{\circ} \mathrm{C}$ ). We thus imagine that cultivation of microbes from core samples will necessitate that sediments be kept cold during retrieval. Decompression during recovery of sampies from the deep sea does not seem to harm them. Microbes sustain decompressions (growth is often stopped or inhibited), but warming is intoler able (they die at abnut 15 to $20^{\circ} \mathrm{C}$ ). Once the cold sample is on board ship, we attempt the cultivations both at low temperatures and at high pressures. The brief decompression of cultures to achieve the transfer of inocula has no detectable adverse effects. Cultivation at atmospheric pressure has been avoided to eliminate or reduce the chance of contamination of cultures with shallow water microbes which continuously enter the deep sea. We hope to use this procedure in the near future to isolate deep-sediment bacteria,

Spores of thermophilic (that is, preferring high temperatures) bacteria have been found in sediments (Bartholemew and Paik, 1966). The ability of these spores to germinate in the presence of heat Er om HLW needs to be determined. Evidence to date with the bacterium CNPT-3 and a few other isolates suggests that the decpsea microbial population wild stop functioning above $15^{\circ} \mathrm{C}$ at 580 bars. Thus, in the $100^{\circ} \mathrm{C}$ regjons of the waste, only spores of thermophilic bacteria could have an effect.

\section{Benthic Boundary Layer studies}

If and when the emplaced canister and waste form disintegrate, radionuclides may interact with sediments so that some substantial fraction or possibly all couid be sorbed (Duursma and Gross, 1971; Heath, et al , 1979). An accident, however, might place radionuclides into the upper portion of the overlying sediment where microorganisms and macrobiota live. We will need to understand the composition, structure, function and dynamic processes of this benthic community and how it interacts with radionuclides. These kinds of data would help determine if recoverability, which is possible, would be necessary.

\section{Community structure}

A box corer technigue for retrieving a reasonably undisturbed portion $10.25 \mathrm{~m}^{2}$ ) of sediment and its community is described by Hessler and Jumars (1974). Analyses of the contents of such cores inform us of the composition and three dimensional distribution of the organisms living in the sediments. Hessler and Jumars (1974, 1977) reported the analyses of twelve box cores from the 
central North Pacific Ocean -- a mid-plate, mid-gyre region (Hollister, 1977) of the kind where HWL might be emplaced. Only a few of the many results from this type of study will be noted here.

The analyses show the area to be oligotrophic (that is, with an apparently small food supply). There were only 84 to 160 individual macrofauna per $\mathrm{m}^{2}$ of sediment. The species present form a diverse set, but any given species is rare. Many of the possible taxa are not represented in the samples, and of the 108 species, 67 were found only once. Polychaetes and tanaidaceans togethe $r$ accounted for 758 of the individuals, with the polychaetes representing 558. A substantial number of polychaetes had sediment in their guts. Although foraminifera and nematodes were not sampled adeguately, there was evidence of a substantial population of these meiofauna (animals which pass through a $1 \mathrm{~mm}$ mesh size screen). Subseguent work by Jumars (1978) shows, among other things, that sediment-ingesting polychaetes stay mainly in the upper $1 \mathrm{~cm}$ of the sediment, but occasionally a few individuals will extend ten to twenty centimeters into the sediment. Bernstein, et al. (1976) and Bernstein and Meador (1979) have observed that the $\overline{r e} \overline{i s}$ an order of magnitude more foraminifera than macrobiota, and that foraminifera have a patchy distribution. Because of their abundance in the samples, the foraminiferan species composition and distributicnal patterns reveal a patch structure, and a persistence of this structure over more than one generation. Details such as this one of community structure may allow for the detection of changes in deep-sea community disturbed by an abnormal level of radionuclides. Burnett (1979) Eound that nematodes do not penetrate much beyond 5 to $10 \mathrm{~mm}$ into the sediment and that they too are abundant, as suggested by Hessler and Jumars (1974). The determination of the food web of ail of the infauna. of their elemental composition, and of their metabolic rate should greatly augment our capability to predict important radionuclide transport pathways. Of course the locomotor and feeding activities of the infauna move both sediments and pore water -- a process referred to as bioturbation.

The above discussion has dealt with those organisms whose existence is intimately tied to the sediments. The visible effects of their activities can be seen in the pictures in Heezen and Hollister (1971). Photography with baited cameras (Isaacs, 1969; Hessler, et al., 1972) has revealed the presence of large, mobile, apparently epibenthic animals. Liparids, rattails, shrimp, amphipods, and other animals have been photographed at abyssaj. depths in the vicinity of bait. There appears to be some interest in the study of rattails (macrourids) as evidenced by the 


$$
-8-
$$

study of McLellan (1977) on their feeding and the study of Merrett (1978) on the distribution of their larval and juvenile stages. A sufficient data base for understanding the role of rattails in mobilizing radionuclides to upper portions of the water column would include a knowledge of the size of the population, its age structure, fecundity, their migratory behavior, their elemental composition, and their radiosensitivity.

We have chosen to pursue at this time the study of one component of this mobile epibenthic group of animals--emphipods. It is practically an axiom of deep-sea biology that these animals will always come to bait on the sea floor (Hessler, et al., 1979). Since they can be caught, many aspects of their population structure can be learned. The age structure of a catch, for example, is mirrored by a plot of the frequency of a given size class versus the size class of the animals. This is a conseguence of their growth by steps recessitated by molting. An abnormal event in the population can lead to a distinctive cohort. If this could be followed by sampling a population over time, then good approximation of age would result.

Studies are also in progress to determine the size of the pcpilations using tag-recapture data. The methodology for tagging amphipods has been developed. We are now dealing with the fielding of tag-recapture experiments at $5700 \mathrm{~m}$ depths and have learned that labeled animals can be recovered.

Among the several species of amphipods (Hessler and Ingram, 1979), Eurythenes gryllus appears to be the most ubiguitous and to have the greatest range in its distribution having been trapped at least $500 \mathrm{~m}$ above the sea floor. Its mobility and ingestion of sediments suggests that $E_{\text {. gryllus could diperse }}$ radionuclides.

Another method for dispersion of matter vertically may exist because of the feeding habits of amphipods and because many lipids are less dense than water. Amphipods are scavengers and do not necessarily consume their entire food source. It is likely that lipid particles are often released and floet to the sea surface. This may not be a major pathway in a normal ocean. A poor epi-seabed disposal practice may result in an abundance of dead animals on the sea floor. The resultant attraction of mobile scavengers may result in the movement of lipid-containing particles (and any bound radionuclides) rapidly and directly to the sea surface (Yayanos and Nevenzel, 1978). 
Community and Organismal Processes

One way to gauge the function of the deep-sea benthic community is to determine its metabolism in a fashion which disturbs it as little as possibie. A free vehicle grab respirometer (FVGR) has been designed and constructed (Smith, et al., 1979) to achieve the capability of measuring metabolism in situ. The instrument is deployed with ballast. On the sea floot, it will respond to commands from the ship. It can gently place 4 boxes (grabs) over the sediments, trapping water and und isturbed sediment. Electrodes detect the utilization of oxygen by the entrapped organisms. Syringes can sample or inject substances into the entrapped water. On command, the grabs are closed retaining the sediment and water on which measurements were made. A final command releases the ballast and the FVGR is recovered. The water samples in the syringes are analyzed chemically. The sediments from the grabs are analyzed for biomass and Eaunal composition.

Measurements with this instrument (Smith, 1978) revealed that benthic community respiration diminished by three orders of magnitude with depth along the Gay Head Bermuda transect of the Atiantic Ocean. Two stations vertically spaced by $2600 \mathrm{~m}$ in the Pacific Ocean, however, showed little difference in community respiration. This similarity may be due to the enriching effects of the california current system.

The FVGR is a useful tool for doing in situ experiments with radionuclides. Already a tracer experiment using a neutronactivatable isotope has been fielded.

We are also studying methods for capturing and retrieving deep-sea animals in a live condition (Yayanos, 1979). If these animals can be maintained in the laboratory, the ir behavior, nutrition, and physiologi can be studied in detail. To date, we have been successful in capturing amphipods at a $5900 \mathrm{~m}$. depth and keeping them at 590 atm and $2{ }^{\circ} \mathrm{C}$ for nearly 17 days. If maintenance of these animals can be extended indefinitely, they should be valuable for studies of radiosensitivity.

\section{Abyssopelagic Fauna}

The depths considered for the disposal of $r$ adioactive wastes (civout 5,Oc m) are known as the abyssal depths of the sea. The extensive amount of water defined by about ten to a few hundred meters above this sea floor and below the $4^{\circ} \mathrm{C}$ isotherm is known as the abyssopelagic zone. This is a poorly understood volume of the oceans because of the difficulty in sampling mobile 
animals which may live there. In an effort to deiermine what lives there, new methods of sampling and catching organisms are being developed. Fisheries that are commercially impo:cant at the present time are above this zone. Radionuclides relecied from a hypothetical deep-sea disposal site would have to penetrate this zone in order to reach man's sea food. One of the mechanisms by which this could happen is by the possible trophic relationships among the animals in this zone which could link the benthic ecosystem to the shallow water one.

A free vehicle midwater net system consisting of oill nets, baited traps, and baited hooks has ecently been dereloped. Tho gill nets are $30.5 \mathrm{~m}$ by $3.3 \mathrm{~m}$ with a $7.6 \mathrm{~cm}$ mesh. The system of nets, hooks and traps has been deployed extensively. Examples of species taken with it are the fish Coryphaenoides armatus (up to $685 \mathrm{~m}$ of $f$ of the sea floor); the Eish Nomoctes alvifrons $(730 \mathrm{~m}$ above the sea floor; and the amphipod Eurythenes gryllus ( $400 \mathrm{~m}$ above the sea floor)(Smith et al., 1979). These are widely regarded as benthic animals. We do not yes know so what extent these animals penetrate the abyssopelagic realm or for what reason they would leave the sea floor and enter the presumably relatively food-poor deep midwater regions of the sea. This evidence for life in this zone reinfurces the notion that there exists a mechanism for actively transporting matrer from the sea floor towards the sea surface. Whether the transport goes all the way to the upper few hundred neters of til. sea ramains to be shown.

Now that we have evidence that there are, indeed, large mobile organisms living in the abys sopelagic ragion, we are developing another type of net to capture them. This net has a $100 \mathrm{~m}$ diameter and $200 \mathrm{~m}$ depth. It is deployed in a folded configuration with ballast. Upon reaching the sea floor, the ballast is released, and the net $r$ ises slowly towards the sea surface, sampling a $100 \mathrm{~m}$ diameter column of the ocean for nearly the full depth of the ocean. The slow ascent, large diameter, and vertical motion should all combine to obviate the net avoidance problem experienced with towed nets.

\section{Radiosensitivity of Deep-Sea Organisms and Ecosystents}

As far as we know, the radiosensitivity of deep-sea organisms has not yet been deternined. But there is a body of research pertaining to the radiosensitivity of shallow water organisms and ecosystems (Templeton, et al., 1970); Blaylock and Trabalka, 1978). There are many problems in dealing with radiosensitivity: determining the dose to the biota; defining and measuring $a$ meaningful biological endpc:nt--this is difficult in experinents 
both with" single organisms as well as with ecosystems; assessing genetic effect; dealing with low-level doses; and assessing many other biological, radigtion and synergistic aspects.

In an effort to gain data on the radiosensitivity of deepsea organisms we intend to: (1) determine the radiation sensitivity of a few bacteria, since these can be cultivated at deepsea conditions in the laboratory; (2) determine aspects of the radiation sensitivity of deep-sea amphipods, since these can be recovered in a living state and maintained in the laboratory for at least a few weeks; (3) identify situations peculiar to the deep sea that might exhibit an enhanced radiosensitivity. For example the pelagic eggs of rattail $f$ ish may be radiosensitive because of the vertical ontogenetic migration they undergo. This stresses them with decompressions of several hundred aimospheres, and possibly with temperature changes if the eggs penetrate the thermocline. The adult rattails may be radiosensitive if their swimbladeer tissues contain oxygen, which is known to greatly enhance radiosensitivity.

Th is kind of information on radiosensitivity in the deef sea will allow an estimate of the appropriateness of using the data on shallow wate: organisms in assessing the impact of accidents on individual organjisms in the deep sea. A determination of the effects on a deep-sea communlty may ultimately reguire an in-situ experiment. 


\section{References}

(1) Anderson, D.R., 1979. "Nuclear waste Disposal in Subseabed Geologic Formations: the Seabed Disposal Program," SAND78-2211, National Technical Information Service, Springfield, Virginia.

(2) Bartholemew, J.W. and Paik, G., 1966. "I jolation and Identification of obligate Thermophilic Spore-korming Bacilli frcm Ocean Basin Cores" Journal of Bacteriology, 92, 635-638.

(3) Bernstein, B.B., Smitr, R., Jumars, P.A., 1978. "Spatial Dispersion of Benthic Foraminifera in the Abyssal Central worth Pacific," Limnology and oceanogcaphy, 23, 401-416.

(4) Bernstein, B.B. and Meedor, J.P., 1979. "Tomporal Persistence of Biological Patch Structure in an Abyssal Benthic Community," Marine Biology, 5I, 179-183.

(5) Blaylock, B.G. and Trabalka, J.R., 1978. TEvaluating the Effects of Ionizing Radiation on Aquatic Organisms, "Advances in Radiation Biology, ?, 103-152.

(6) Burnett, B.R., 1979. "Benthic Biologicel stuâies: Microbiota and Meiofalına" in Seabed Disposal Program Annual Report, 1978. National Technical Information Service, springfiele, Virginia.

(7) Dietz, A.S. and Yayanos, A.A., 1978. "Silica gel method for isolating and studying bacteria under hydrostatic pressure," Applied and Environmental Microbiology, 36, 966-6B.

(8) Duursma, E.K. and Gross, M.G., 1971. "Marine Sediments and Radioactivity," U.S. National Academy Sciences, Washington. D. C.

(9) European Niclear Energy Agency, 1968. "Radioactive Waste Disposal Operation into the Atlantic, 1967" ENEA/OECD, Paris, 74 pp.

(10) Gieskes, J.M., 1975. "Chemistry of Interstitial waters of Mar ine Sediments' Annual Review of Earth and Planetary Sciences. 3, 433-453.

(II) Heath, R., Epstein, G.P., Leinen, M. and Prince, R.A., 1979. "Geotechnical and Sedimentclogical Assessment of Deep Sea Sediments," in SAND7B-1359, National Technical Information Service, Washington, D.C., 33-55.

(12) Heezen, B.C. and Hollister, C.D., 1571. "The Face of the Deep." oxford University press, New York, $659 \mathrm{pp}$.

(13) Hessler, R.F.., and Jumars, P.A., 1974. "Abyssal Community Analysis from Replicate Box Cores in the Central North Pacific," Deep-Sea Research, 21, 185-209. 
(14) Hessler, R.R., and Jumars, P.A., 1977. "Abyssal Communities and Radioactive Waste Disposal," Ocaanus, 20, 41-46.

(15) Hesslor, R.R., Isaacs, J.D. and Mil1s, E.L., 1972. "Giant Amphtfod frcin the Abyssal Pacific ocean," Science, 175, 636-637.

(16) Hessler, R.R., Ingram, C.L., Yayanos, A.A., and Burnett, B.R., 1978. "Scavenging Amphipods from the Floor of the Phillippine Trench" Deep-Sea Research, 25, 1029-1047.

(17) Hessler, R.R. and Ingram, C.L., 1979. "Benthic Biological Studies" In Seabed Disposal Program Annual Report, 1978, Nationa? Technical Information Service, springfield, Virginia.

(18) Hollister, C.D., 1977. "Annual Report for Sandia Seabed Progran" in Report SAND77-1270, National Technical Information Service, springfield, virginia (1977) 2.5-38.

(19) Isaacs, J.D., 1969. "The Nature of Oceanic Life," Sicientific American, 221, $146-162$.

(30) Japan Society for the Promotion of Science, 1956. "Research in the Effects and Influences of the Nucisar Bonb Test Explosions" Vol. I and II., Jeno, Tokyo, $1824 \mathrm{pp}$.

(21) Jumars, P.A., 1978. "Spatial Autocorrelation with RUM (Remote Underwater Manipulator): Vertical and Horizontal structure of a Bathyal Benthic Community," Deep-SeaResearch, 25, 589-604.

(22) Krumbein, W.E. (Edicor), 1978. "Environmental Biogeochemistry and Geonicrobiology" Vol. 1, 2, 3, Ann Arbor Science, Ann Arbor, Michigan.

(23) Longhurst, A.R., 1976. "Vertical Migration" in The Ecology of the Seas (Cushing and walsh, Editors) W.B. Saunders Co., philadelphia, $116-140$.

(24) McElroy, J.L, and Burns, R.E.. 1979. "Nuclear Waste Management Status and Recent Accomplishments," Repoit NP-1087, Electric Power Research Institute, Palo Alto, California.

(25) McLellan, T., 1977. "Feeding strategies of the Macrourids," Deep-Sea Research, 24, 1019-1036.

(26) Merrett, N.R., 1978. "On the Icentity and Pelagic Occurrence of Larval and Juvenile stages of Rattail Fishes (Family Macrouridae) from $60^{\circ} \mathrm{N}, 20^{\circ} \mathrm{W}$ and $53^{\circ} \mathrm{N}, 20^{\circ} \mathrm{w}, "$ Dees-Sea Research, 25, 147-160. 
(27) Noshkin, V.E., Wong, K.M., Jokela, T.A., Eagle, R.J. and Brunk, 3.L., 1978. "Radionuclides in the Marine Environnent Near the Farallon Islands," Repoit UCRL-52381, Ciniversity of California, Livermore, Calirornia, $17 \mathrm{pP}$.

(28) "Ocean Duinping," 1970, Council on Environmental Quality, Siperintendent of Documents, U.S. Government Printing office, Washington, D. C.

(29) Pearcy, W.G., Krygier, E.E. and Cutshal1, N.H.,1977. "Biological Transport of 2 inc-65 into the Deep Sea" Limnology and Oceanography, 22, 846-855.

(30) Preston, A., 1975. "The Radiological Conseguences of Release from Nuclear Facilicies to the Aguatic Environment" in Impacts of Nuclear Releases into the Aquatic Environment, IAEA, vienna, 3-23.

(31) Russel1, F.S., 1976. "The Eggs and Planktonic stages of British Marine Fishes" Academic Press, N.Y., $524 \mathrm{pp}$.

(32) Schaefer, M.D. 1960, New Research Required in Support of Radioact ive Waste Disposal" in Disposal of Radioactive wastes, IAEA, Vienna.

(33) Smith, K.L., white, G.A., and Laver, M.B., 1979. "Oxysen Uptake and Nutrient Exchange of Sediments Measured In Situ Using a Free Vehicle Grab Respironeter," Deep-Sea Research, 26, $337-346$.

(34) Smith, K.L., Je., 1978. "Benthic Community Respiration in the N.W. Atlantic ocean: In situ Measurements from 40 to 5200 Meters," Marine Biology, 47, 337-347.

(35) Smith, K.L. Jr., White, G.A., Laver, M.B., McConnaughey, R.R., and Meador, J.P., 1979. "Free Vehicle Capture of Abyssopelagic Animals," Deep-Sea_Research, 26, 57-64.

(36) Templeton, W.L., Nakatani, R.E., Held, E.E., 1971. "Radiation Effects" in Radioactivity in the Marine Environment, National Academy of sciences, Washington, D.C.

(37) Wishner, R., 1977. "An Ocear Ecosystem Model" in SAND77-1270, National Technical Information Service, Springfield, Virginia, $356-364$.

(38) Yayanos, A.A. and Van Boxtel, R.: "Progress Report: Determination of the Microbial Content of Ocean Sediments" in ibid. 281-288. 
(39) Yayanos, A.A., Dietz, A.S. and Van Boxtel, R., 1979. "Isolation of a Deep-Sea Barophilic Bacterium and some of Its Growth Characteristics," Science, 205, 808-810.

(40) Yayanos, A.A. and Nevenzel, J.C., 1978. "Rising-Particle Hyoothesis: Rapid Ascent of Matter from the Deep Ocean," Naturwissenschaften, $\underline{65}$.

(41) Yayanos, A.A., 1978. "Recovery and Maintenance of Live Amphipods at a Pressure of 580 Bars from an Ocean Depth of 5700 Meters," Science, 200, 1056-1059. 